\title{
Developing Thematic-Integrative Learning Module with Problem-Based Learning Model for Elementary School Students
}

\author{
Monika Handayani \\ Department of Primary Education, Universitas Terbuka. \\ Jalan Cabe Raya, Pondok Cabe, Pamulang, Kota Tangerang Selatan, Banten, 15418, Indonesia \\ Corresponding Author. E-mail monika@ecampus.ut.ac.id \\ Received: 31 May 2017; Revised: 4 September 2018; Accepted: 3 October 2018
}

\begin{abstract}
The study aims to (1) produce a integrative thematic learning module with PBL model which is viable, and (2) determine the effectiveness of the module towards the independent learning and learning outcomes of year five students of SD Negeri Pudjokusuman 1 Yogyakarta. This research was research and development. The subjects were teachers and students of year five students of SD Negeri Pudjokusuman Yogyakarta. Data analysis technique used paired sample t-test and independent sample t-test with significance level of 0.05 . The results of this study are (1) an appropriate integrative thematic learning module with problem-based learning model. The proof of feasibility of the product is based on the test results of matter experts, the media experts test, the response of the teachers, and the response of the students. (2) The result shows that the developed module is effective to improve student's independent learning and learning outcomes. It is based on the results obtained in the field trials showing $\mathrm{p}<0.05$ in cognitive learning outcomes and independent learning. Futhermore, based on the observation results student's in affective and psychomotor learning outcomes of the students in experimental class have a higher percentage than of the control class.
\end{abstract}

Keywords: learning module, problem-based learning, independent learning, learning outcomes

How to Cite: Handayani, M. (2018). Developing thematic-integrative learning module with problem-based learning model for elementary school students. Jurnal Prima Edukasia, 6(2), 166-176. doi:https://doi.org/10.21831/jpe.v6i2.14288

Permalink/DOI: https://doi.org/10.21831/jpe.v6i2.14288

\section{Introduction}

The curriculum changes that done at this time from the curriculum unit-level education (KTSP) became the curriculum 2013 is accomplished as a solution for improving the quality of education and as an improvement over the previous curriculum i.e. KTSP. Curriculum 2013 is expected to enable students to build knowledge, develop the attitudes and skills.

The study on the primary level which is implemented in curriculum 2013 is thematicintegrative learning. Thematic learning is integrated learning that uses the theme to associate multiple subjects so as to provide meaningful experiences to students (Majid, 2014, p. 80). Thematic-integrative learning encourages students to learn independently and active in finding and acquiring the knowledge itself.

In curriculum 2013, the primary material which is used in integrative thematic learning is a handbook of students and teacher. Learning materials are all materials (information, tools, as well as text) that are arranged systematically with demonstrated competence that must be mastered and used in the student learning process with the planning and implementation of learning study (Prastowo, 2015, p. 17). Ideally in curriculum 2013 the learning book of student and teacher only as guidelines on student-centred learning.

In fact, the practice of learning with Curriculum 2013 in SD Negeri Pudjokusuman 1 has not maximum yet because the learning process has not been applying the integrative thematic learning completely. It is supported from interviews with four teachers of grade $\mathrm{V}$ on 28 September to 1 October 2015. A teacher in class V C explained the material on Handbook students that is too broad if should teach in-depth. Then, the learning is too much time-consuming. In another side, the material in the student's book is not complete such as the examples and detailed material reviews. This case makes the teacher should actively explain additional material with 
Jurnal Prima Edukasia, 6 (2), July 2018 -167

Monika Handayani

the textbooks of sufficient material to KTSP students.

Based on observation result is known that the addition of material in KTSP book is causing the way of the teacher to teach also change no longer complies with curriculum 2013 because the teacher became more active in the learning process. The interview result also shown that the entire teacher of grade $\mathrm{V}$ had never made such a module supporting materials or textbook to complete a shortage in the student handbook.

A teacher in grade V B explained that some of the material in the student handbook is less appropriate to the characteristics of elementary school students because of the concept use a reverse explanation from difficult to easy. It also impacts the students' understanding independently the material in the students' handbook. Here, the teacher should always provide more explanation to students. The teacher also explains that the independence of students learning is still less because the initiative of students to seek information from other sources is still lacking. And, nearly $75 \%$ of students typically rely solely on information from the Handbook. Moreover, based on the need analysis on the independence learning drew the conclusion that the entire independence learning in students of grade $\mathrm{V}$ is still lacking. Students have trouble in finding information that is relevant to the material which studied because students just focused on the student handbook. So, the students are having trouble in finding information that relates to problems solving due to lack of learning materials and learning resources. The result of observation also showed that students are less able to understand the instructions of the Handbook and students rely on the teacher's command during the learning activity.

In addition, from the interviews result from teachers explained that the average of learning outcomes of students' cognitive is still below the KKM i.e. 70, and psychomotor and affective learning outcomes of students are also still lacking. Based on the need analysis of the observation on the learning outcome is known that most students also have difficulty in analyzing information and also less able to assess the opinions of friends and another group presentation results.

Based on the results of the interview are also known that a teacher needs learning materials in complying with the Curriculum 2013 and able to facilitate students in increasing the independence and learning outcome. As stated by Musriadi, Rubiah \& Jailani (2016, p. 39), the development of teaching materials is important for the teacher to improve the quality and efficiency of the learning process. The developed materials have an important role both for the teacher and students. It needs to develop the learning materials such as modules to support the process of learning in the curriculum 2013 aiming to achieve the learning objectives.

The module is a type of learning materials that are able to support the learning process because the module is designed to encourage the student to learn independently. The module is learning materials that arranged systematically with easy to understand language by students according to age and level of knowledge. As the result, the students can study independently with minimal guidance or assistance from educators (Prastowo, 2015, p. 106). The module is learning materials that arranged systematically with easy to understand language by students according to the characteristics of the students. In this case, the module can facilitate the students to learn independently with minimal guidance or assistance from educators. And, the students are able to achieve the determined objectives as well as the results of a study.

Thematic-Integrative learning is learning that applied in the implementation of Curriculum 2013. Fogarty (1991, p. 76) explained that "The integrated curricular model represents a crossdisciplinary approach similar to the shared model." Thematic-integrative learning is able to facilitate alignment between disciplines of multiple subjects aiming it can see the connectivity between one learning and another. Thematicintegrative learning combines the field of study by set the curricular priorities, and finds the skills, concepts and attitudes that overlap in some studies (Wangid, Mustadi, Vera, \& Arifin, 2014, p. 178). Integrating multiple subjects' makes the process of delivery the study easier for elementary school students and encourage students has the knowledge, attitudes, and skills.

Model of Problem-Based Learning (PBL) is one of the models of constructivism learning theory that facilitate students to actively solve problems through the giving problem. PBL is a model in student-centred approach that encourages students to have the skills of solving the problem based on real problems (real world) (Arends \& Kilcher; 2010, p. 326 and Demirel \& Dagyar, 2016, p. 2117). PBL models are a model of learning which presents problems with topics of the students' real life. So, it is able to actively encourage the students to develop problem- 


\section{Jurnal Prima Edukasia, 6 (2), July 2018 -168}

Monika Handayani

solving skills and deepen the understanding of the concept of learning.

Independent learning is identified by study with own accord without any guidance or with minimal guidance from others. The students' Independence learning is seen in students' ability in solving the problems based on their own business (Holstein, 1994, p. 9; Chester 2009, p. 12, and Koenig, 2010, p. 109). Students who have independence learning feel responsible for their studies. "Independent learning is recognized as an important predictor of students' academic motivation and achievement. Independent learning mostly is driven by the student's own initiative, choice and self-learning responsibility "(Sumantri \& Satriani, 2016, p. 512). Independence of learning is the ability of a person to be able to learn independently in a proactive, organize, solve the problem and find a solution as well as responsible for the selected decision.

The Learning Outcomes are benchmarks of the success of the learning objectives that have been implemented. The results of the study are based on learning objectives as measured through three domains, namely cognitive, affective, and psychomotor (Yastika \& Haryanto, 2016, p. 108; Miller, 2008, p. 19). The results of the study can be seen from the changes in student behaviour because of the change in behaviour based on the achievement of student understanding on certain material. The Students stated to be a success in following the learning if the students are able to understand the material and using their knowledge to solve new problems and learn the new situation (Anderson \& Krathwohl, 2001, p. 65). The result of the study is the competence or abilities including cognitive, psychomotor and affective that achieved or controlled by students after following the process of learning.

The results of the study that assessed this research adjusted to the characteristics of the elementary students. So, it restricted not to all levels on the results of the study are measured. On the cognitive realm is based on Bloom's taxonomy with the level of knowledge, comprehension, application, and analysis. The affective domain includes the assessment of the ability to receive, respond, assessing, and organizing. The psychomotor domain includes the capabilities of perception, set, guided response, mechanism, and complex overt response.

In this study, the development product is the development of thematic-integrative learning module with Problem-Based Learning (PBL). Integrative Thematic learning module with $\mathrm{PBL}$ is a module which is developed with the characteristic of integrative thematic learning and applying the model step of PBL. Then, it is able to encourage students to actively engage in solving the real-life problem. Integrative thematic learning module with PBL specially developed in themes 3 "Lingkungan Sahabat Kita" and sub-theme 3 "Usaha Pelestarian Lingkungan.'

Based on the description, the purpose of this research was a) producing an integrative thematic learning module with PBL to encourage the independent learning and learning outcomes of students grade $\mathrm{V}$ at SD Negeri Pudjokusuman 1 Yogyakarta, and $b$ ) find out the effectiveness of integrative thematic learning modules with PBL to encourage self-reliance learning and learning outcomes of student grade V at SD Negeri Pudjokusuman 1 Yogyakarta.

\section{Method}

This research was research and development which purposed to develop a product. This research conducted in SD Negeri 1 Pudjokusuman Yogyakarta on May 2016. The subject of the initial field trials carried out to 15 students on class V B. Meanwhile, the field trials conducted to 30 students in class VB. The subject of field test was the class VA, VC, and VD at SD Negeri 1 Pudjokusuman Yogyakarta. Then, the problem was tested on 54 students of grade 5 at SD Negeri Lempuyangwangi Yogyakarta.

This research used the model of research and development that included (1) a preliminary study, (2) planning, (3) product design, (4) initial trials, (5) the revision of initial trial results, (6) field trials, (7) the revision of the results of field trials, (8) field trials implementation, (9) the revision of the final product, and (10) dissemination and implementation (Borg \& Gall, 1983, p. 775).

The data on this research was a form of data (1) identification of the problem and preliminary information, (2) the feasibility of the validity of the module, the response of teachers as well as the response of the students, (3) the effectiveness of this aspect of the independence learning and the learning outcome.

Data collection techniques were the structured interviews, unstructured observation, assessment products, questionnaire the response of teachers and students, scale independence of learning, structured observation of independent learning, tests of cognitive learning results, observations affective learning outcomes and 
observational of psychomotor learning outcomes. The instruments were interview guidelines of assessment sheet, observation sheet of product media expert and expert material, form response sheet material of teachers and students, the sheet scale of independent learning, independence learning of observation sheets, question test, affective, and psychomotor learning outcomes observation sheet.

Data analysis method before the research was unstructured interview and observation result. And then, the obtained data were analyzed using descriptive techniques. For the data of product development were analyzed using qualitative and quantitative data. Product feasibility data were analyzed by scoring and the converted to be the qualitative data. The data on the test of learning cognitive and independence learning scale were analyzed using statistical analysis. The data of observation independence learning outcome, affective and psychomotor learning outcomes were analyzed using scoring and converted into qualitative data.

The quantitative data is done by calculating the mean of total score from every aspect and the indicators. Those score calculated by the formula of mean. After that, it changes the average score into a criteria scale with five categories which are very good (5), good (4), adequate good (3), less good (2), and very less good (1). The score is then converted to qualitative data with formulas in table 1 .

Table 1. The Mean Interval Conversion of Score Assessment

\begin{tabular}{ccc}
\hline Score & Interval score & Category \\
\hline$A$ & $X>X_{i}+1,8 \mathrm{SB}_{i}$ & Very Good \\
$B$ & $X_{i}+0,6 \mathrm{SB}_{\mathrm{i}}<\mathrm{X} \leq \mathrm{X}_{\mathrm{i}}+1,8 \mathrm{SB}_{\mathrm{i}}$ & Good \\
$\mathrm{C}$ & $\mathrm{X}_{\mathrm{i}}-0,6 \mathrm{SB}_{\mathrm{i}}<\mathrm{X} \leq \mathrm{X}_{\mathrm{i}}+0,6 \mathrm{SB}_{\mathrm{i}}$ & Adequate \\
Good \\
$\mathrm{D}$ & $\mathrm{X}_{\mathrm{i}}-1,8 \mathrm{SB}_{\mathrm{i}}<\mathrm{X} \leq \mathrm{X}_{\mathrm{i}}-0,6 \mathrm{SB}_{\mathrm{i}}$ & Less Good \\
$\mathrm{E}$ & $\mathrm{X} \leq \mathrm{X}_{\mathrm{i}}-1,8 \mathrm{SB}_{\mathrm{i}}$ & Very Less \\
& & Good \\
\hline
\end{tabular}

Description:

$\mathrm{X}_{\mathrm{i}}$ : Average of ideal score $=1 / 2($ maximum score + score a minimum)

$\mathrm{SB}_{\mathrm{i}}$ : ideal of standard deviation $=1 / 6($ score maximum - minimum score)

$\mathrm{X}$ : Score

In this research, was set out the results of the score a minimum is " $\mathrm{B}$ " with "Good" criteria. Thus, the development product of thematicintegrative module was appropriate and effective used as a module.

The analysis for cognitive learning result was done by tabulating the data of cognitive learning test result through converting the data according to Arikunto (2013, p.281).

Table 2. The Directive of the effectiveness of cognitive learning result

\begin{tabular}{cc}
\hline $\begin{array}{c}\text { The Number Presentation of } \\
\text { Students completeness }(\%)\end{array}$ & Effectiveness \\
\hline $\mathrm{X}>80$ & Very Good \\
$60<\mathrm{X} \leq 80$ & Good \\
$40<\mathrm{X} \leq 60$ & Enough \\
$20<\mathrm{X} \leq 40$ & Less \\
$\mathrm{X} \leq 20$ & Very Less \\
\hline
\end{tabular}

Description:

$\mathrm{X}=\frac{\Sigma x}{n} \mathrm{x} 100 \%$

$\mathrm{X}=$ the presentation of the number of Students completeness

$\Sigma \mathrm{x}=$ number of students completeness

$\mathrm{n}$ = number of students

Analysis of cognitive learning outcomes reached a minimum percentage of the amount completeness with "good". The analysis of the increased of the independent learning and learning outcome used the calculation of the gain score.

Gain score $=\frac{\text { posttest score }- \text { pretestscore }}{\text { maximum score-pretest score }}$

Further analysis of the effectiveness of the test conducted to find out the differences the increasing independent learning and learning outcome. This analysis conducted with prerequisites tests which are the normality and homogeneity test. After paired sample t-test and independent sample, it continued to the t-test.

\section{Finding and Discussion}

In the preliminary study, the developed module of thematic-integrative learning with PBL for students of grade V at SD Negeri Pujokusuman 1 was performed in 3 steps. The steps were: the study of literature, observation and interviews, and document review. Based on the results of the need analysis, the teachers need a module as materials in line with the characteristics and needs of students.

The next stage, it conducted the planning and developing in product development. The planning was determining the purpose of product development; estimate the time and the limitations of the research; and collect the appropriate materials as well as the planned trial of the product. The developing of the products carried out using the Corel Draw X4 program and other supporting applications. The developed module was through the validation stage from material and media experts. And then, it 
continued to test to obtain the response of the students and the teacher.

Analysis Result of the Validation from Material Experts

The analysis result of the validation by material expert consisted of aspects of usability, feasibility, propriety, and accuracy. Figure 1 presented the results of an assessment module by the expert material.

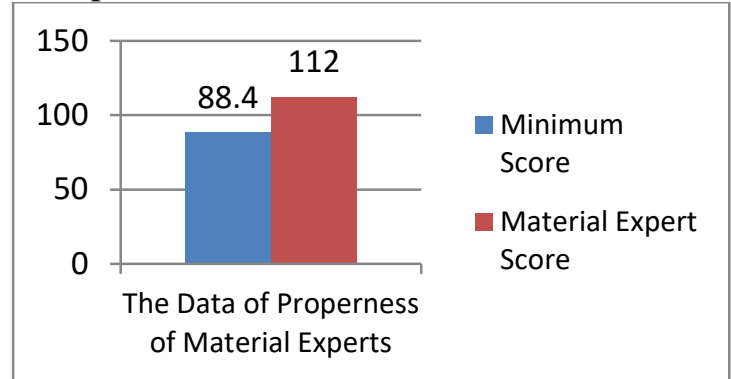

Figure 1. The Result of the Module Assessment by the Material Experts

Based on Figure 1, the overall score for material aspect was 112 with the category "very good." The obtained score has exceeded the minimal score. Thus, the assessment of material aspect by the material expert on the developed product was "proper."

Analysis Result of the Validation from Media Experts

The analysis result of validation by media expert consisted of feasibility, propriety, and accuracy. Figure 2 presented the results of the assessment modules by media expert.

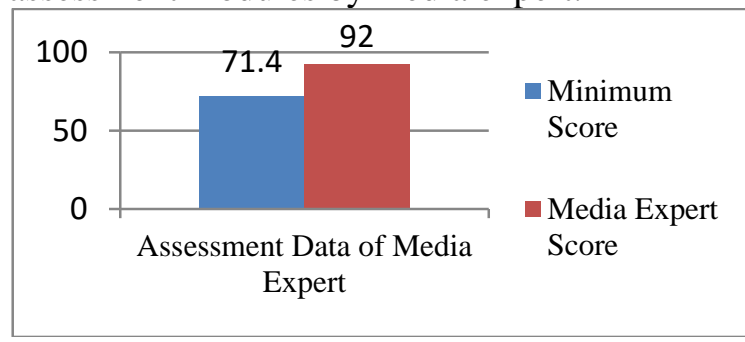

Figure 2. The Result of the Module Assessment by the Media Experts

Based on Figure 2, the score on media aspect was 92 with the category of "very good." The obtained score has exceeded the minimum score of 92> 71.4. Thus, the assessment of media expert on developed products was "proper."

The Result of the Test

The data of test used to assess the eligibility of material of cognitive learning outcome. The question trials provided after the question instrument has validated by the experts. The question on trials conducted in SD Lempuyangwangi Yogyakarta aiming to test the validity, reliability, the capacity of distinguishing, and difficulty of the question. Then, based the analysis result, it might formulate 3 questions which may use as pre-test and post-test.

The Result of the Initial Field Trial

The initial field trials conducted to the teacher of grade VB and 15 students of grade VB. Assessment aspect of the teacher's response consisted of usefulness, appropriateness, and accuracy. Meanwhile, the aspect of students' response is the product usefulness for students. Figure 3 presented the data of teachers' response.

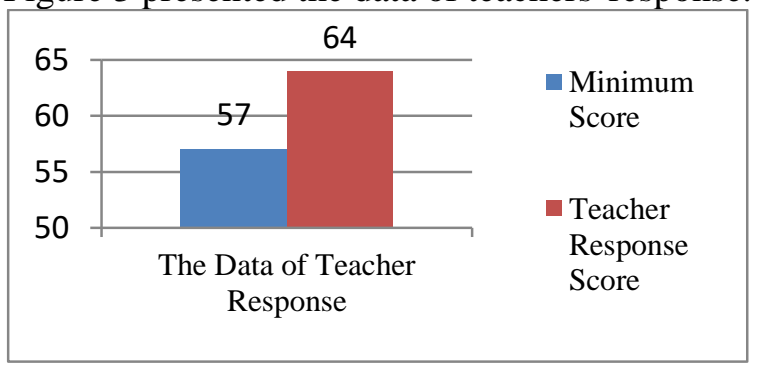

Figure 3. The Result of Teachers' Response in a Initial Field Trial

Based on Figure 3, the total score of the response of teachers on the first field trials was 64 with a category of "Good." So, the module can proceed to the next stage.

In addition, the analysis results of the students' response presented in Figure 4.

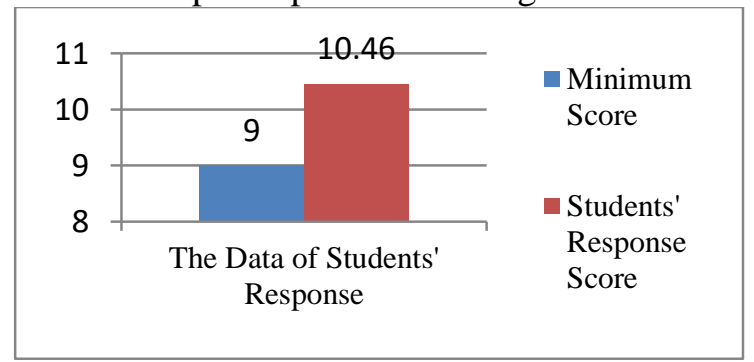

Figure 4. The Result of Students' Response on the Initial Field Trials

Based on Figure 4, the gain score of students on an initial field test was 10.46 with the "good" category. Based on the data, concluded that the developed module may continue to test the products with more subjects.

Field Trial Results

After conducted revisions, the module is re-tested to 30 students of grade V B and all Teachers in grade $\mathrm{V}$ in SD Negeri Pudjokusuman 
1. Figure 5 presented the results of the teachers' response.

\begin{tabular}{|r|cl|}
\hline 80 & \multicolumn{1}{c|}{71} & \\
60 & 57 & Minimum \\
40 & & Score \\
20 & & \\
0 & & \\
& Data Respon Guru & Teacher's \\
& Response \\
& Score \\
& & \\
\hline
\end{tabular}

Figure 5. The Result of Teacher's Response on Field Trials

Based on Figure 5, the total of teachers' response toward the module obtained a score of 71 with a category of "very good." Based on the results, then it may be inferred that the module is already feasible to apply to field test.

Data on the student's response also experience an increase in the field trials. Figure 6 presented the results of the analysis of the student's response.

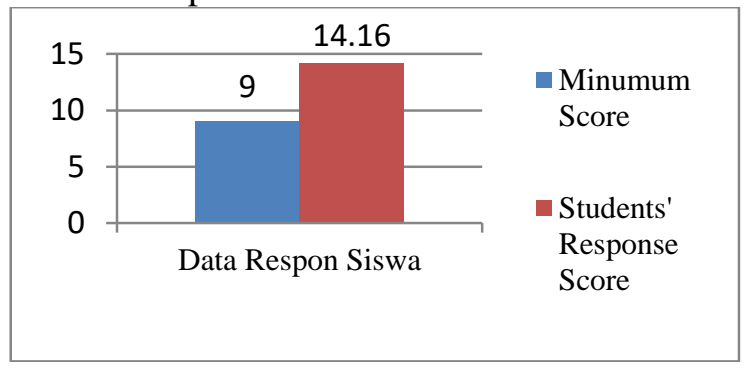

Figure 6. The Result of Students' Response on Field Test

Based on Figure 6, the total score of the field trials was 14.16 with a category of "very good." Based on the results, the product can be used in the field test.

\section{The Results of the Field Test}

The field test conducted to find out the effectiveness of the developed products. Field test consisted of questionnaire data of independent learning, observation the result of independent learning, observation the result of affective learning, observation the result of psychomotor learning, and the test result of cognitive learning. The field test conducted at SD Negeri Pudjokusuman 1 with 3 parallel classes that are V A and V D (experiments class) and V $\mathrm{C}$ class (control class).

The data on students' independent learning obtained through observation and scale results. Then, data on the result of independent learning scale in form of pre-test and post-test were analyzed using analysis of the prerequisites and test of independent t-test and paired t-test. According to gain score, the control class (VC) obtained a score of 0.51 , the experiment class (VA) obtained a score of 0.67 , and the class experiment class (VD) obtained a score of 0.69.

Kolmogorov Smirnov test used to obtain the result of the normality test of independent learning on the experimental class and control class. Based on the results of the normality test, all data on the control class and the experiment class normally distributed with $p>0.05$. Moreover, based on the homogeneity, all data was homogeneous with $\mathrm{p}>0.05$.

After the prerequisite test, it continued to test the increasing of the independent learning using paired sample t-test and independent sample t-test. On the test of paired sample t-test conducted with analyzing the post-test and pretest result on both experiment class (V A and V D). The results of the different test of independent learning are presented in Table 3.

Based on Table 3, the independent learning has signification score less than 0.05 i.e. 0.000 . So, there was a significant increase in the experiment class before and after using the module.

The data on independent learning also tested using the Independent Samples t-test. The test results in Table 4 showed the Independent Sample t-test in the control group and the experimental group.

Based on table 4, the t-test results of independent learning obtained that the significance value of 0.003 on experimental class $\mathrm{V}$ A and experiment classes V D at 0.000 . With this result, the significance value is able to meet the criteria of $\mathrm{p}<0.05$. In sum, $\mathrm{H} 0$ rejected and $\mathrm{Ha}$ accepted.

Table 3. The different Test of Data on Independent Learning

\begin{tabular}{ccccc}
\hline \multirow{2}{*}{ Result } & \multicolumn{2}{c}{ VA } & \multicolumn{3}{c}{ VD } \\
\cline { 2 - 5 } & Pre & Post & Pre & Post \\
Mean & 50,93 & 70,41 & 51,06 & 71,06 \\
Sig (2-tailed) &, 000 &, 000 &, 000 &, 000 \\
Analysis & $\mathrm{p}<0,05$ & $\mathrm{p}<0,05$ & $\mathrm{p}<0,05$ & $\mathrm{p}<0,05$ \\
\hline
\end{tabular}


Jurnal Prima Edukasia, 6 (2), July 2018 -172

Monika Handayani

Table 4. The Result of Independent Sample t-test of Independence Learning

\begin{tabular}{|c|c|c|c|c|}
\hline Data & Class & Sig 2-tailed (p) & Condition & Description \\
\hline \multirow{2}{*}{ Pre } & $\begin{array}{l}\text { Control } \\
\text { Eks. (VA) }\end{array}$ & 0,821 & $\mathrm{p}>0,05$ & Ho accepted \\
\hline & $\begin{array}{l}\text { Control } \\
\text { Eks. (VD) }\end{array}$ & 0,852 & $\mathrm{p}>0,05$ & Ho accepted \\
\hline \multirow{2}{*}{ Post } & $\begin{array}{l}\text { Control } \\
\text { Eks. (VA) }\end{array}$ & 0,003 & $\mathrm{p}<0,05$ & Ho rejected \\
\hline & $\begin{array}{l}\text { Control } \\
\text { Eks. (VD) }\end{array}$ & 0,000 & $\mathrm{p}<0,05$ & Ho rejected \\
\hline
\end{tabular}

Table 5. The test of different Result of Cognitive Learning

\begin{tabular}{ccccc}
\hline \multirow{2}{*}{ Result } & \multicolumn{2}{c}{ VA } & & \multicolumn{2}{c}{ VD } \\
\cline { 2 - 5 } & Pre & Post & Pre & Post \\
Mean & 59,77 & 81,03 & 59,88 & 79,65 \\
Sig (2-tailed) &, 000 &, 000 &, 000 &, 000 \\
Analysis & $\mathrm{p}<0,05$ & $\mathrm{p}<0,05$ & $\mathrm{p}<0,05$ & $\mathrm{p}<0,05$ \\
Description & Ho rejected & Ho rejected & Ho rejected & Ho rejected \\
\hline
\end{tabular}

Table 6. The Test Result of Independent Sample t-test on the Cognitive Learning

\begin{tabular}{clccc}
\hline Data & Class & Sig. 2-tailed (p) & Condition & Description \\
\hline \multirow{2}{*}{ Pre } & Control Eks. (VA) & 0,965 & $\mathrm{p}>0,05$ & Ho accepted \\
& Control Eks. (VD) & 0,994 & $\mathrm{p}>0,05$ & Ho accepted \\
Post & Control Eks.(VA) & 0,002 & $\mathrm{p}<0,05$ & Ho rejected \\
& Control Eks.(VD) & 0,020 & $\mathrm{p}<0,05$ & Ho rejected \\
\hline
\end{tabular}

Moreover, the data of independent learning also took from the observation that conducted on each meeting. Figure 7 presented the observations result of the independent learning of student at each meeting.

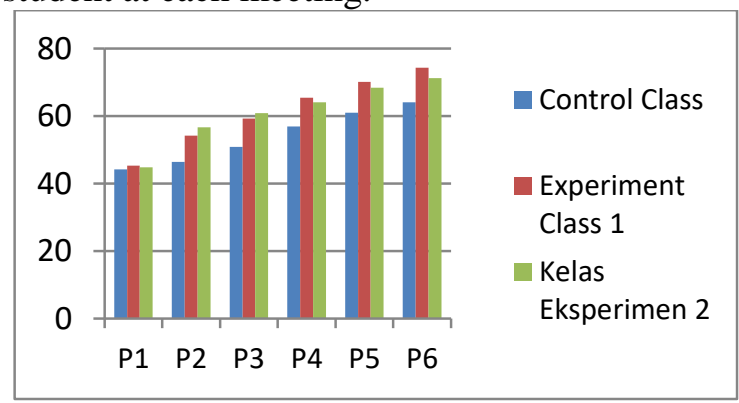

Figure 7. Observation Result of Students' Independent Learning

Based on Figure 7, the average score on the observation results of experiments class is higher, and significant increases compared to the average on the results of observation on the control class.

Based on the results of the test of paired ttest and the independent t-test, and the results of the observations, it may know that independent learning of student in the experiment class significantly increased with the significance level $\mathrm{p}<0.05$. In sum, there is a significant difference between the experimental and control class. Thus, it concluded that the thematic-integrative module with PBL is effective in improving the independent learning.

The data of cognitive learning obtained from question items, while the data of affective and psychomotor obtained from observation. The data on the result of cognitive learning is a question on pre-test and post-test which analyzed using the prerequisites and independent $t$-test and paired t-test. Based on the result of gain score, the score obtained on the control class (V C) of 0.34 , the experiment class ( $\mathrm{V} A)$ of 0.53 , and the experiment class (V D) of 0.49 .

Meanwhile, the result of the normality test that conducted in the experiment class and the control class obtained the data normally distributed with $p>0.05$. And, homogeneity test toward pre-test and post-test data on control class and the experiments class showed that the result of significance score obtained $p>0.0 .5$. In sum, Ho is accepted and homogeneous.

The next test conducted a paired sample ttest to both the experiment class. The result of paired sample t-test on the cognitive learning is presented in Table 5.

Based on table 5, the significance values are less than 0.05 at both the experiment class i.e. 0.000 . It concluded that there was a significant increase between the average score of the experiment class before and after using an thematicintegrative learning module with PBL. 
In addition, data the pre-test and post-test of cognitive learning also tested through independent sample t-test. The results of independent sample t-test on the cognitive learning are presented in Table 6.

Based on table 6 , there is a difference between the pre-test and post-test results in the control class and the experiment class (both class of V A and V D). Pre-test results showed the significance of the three class $p>0.05$. So, Ho accepted, meanwhile in three class, the results of post-test showed the significance value of $\mathrm{p}<0.05$. So, Ho rejected. Thus, concluded that the final ability (post-test) on the control class and the experiment class has a significant difference because Ha accepted and Ho rejected.

Meanwhile, the affective learning outcomes and psychomotor learning results obtained from observations on each meeting. The observation results of affective learning presented in Figure 8.

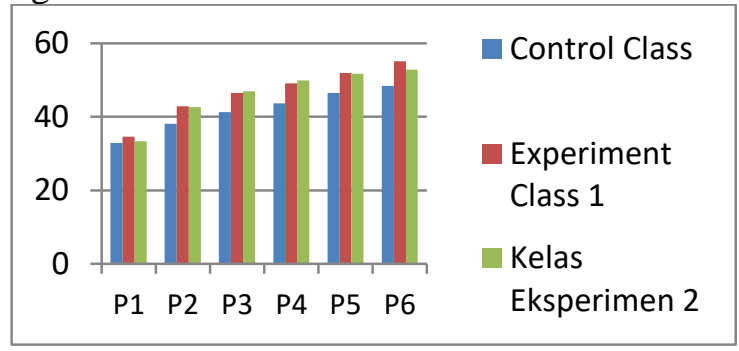

Figure 8. Observation Result on affective learning outcome.

Based on figure 8 , the score of observation on the affective learning in the experiment class increased higher than the control class.

In addition, the observation results of the psychomotor learning also increased at each meeting. The results of observation on psychomotor learning outcomes are presented in Figure 9.

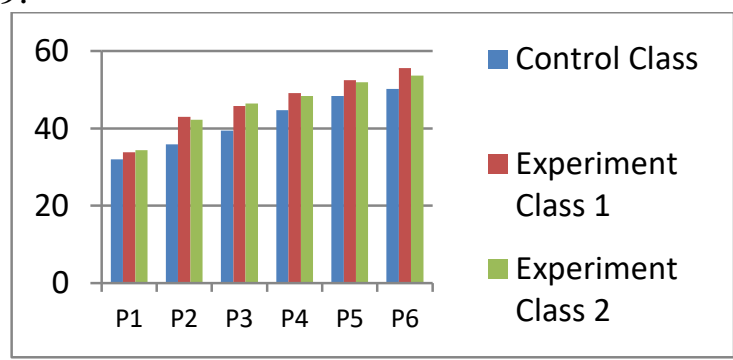

Figure 9. Observation Result on Psychomotor learning outcome

Based on Figure 9, the observation results of the psychomotor learning outcome in the experiment class increased higher than the control class. Based on the results, concluded that the use of thematic-integrative learning modules with PBL on the experiments class was able to significantly increase the result of student learning of cognitive, affective and psychomotor than the control class.

\section{The Analysis of the Final Product}

Thematic-integrative learning modules with Problem-Based Learning (PBL) can support the learning activity on curriculum 2013. The uses of material or supporting materials in the study were able to encourage the students actively involved in the learning process. The use of material or learning materials is appropriate to the characteristics of the students and the curriculum. Thematic-integrative learning modules with PBL based on curriculum 2013. Learning uses the thematic-integrative module with Problem-Based Learning encourages the students to work in a group to solve the problem collaboratively. So, the students can be more responsive in thinking and acting. As expressed by Johnson \& Johnson (Goodman, 1990, p. 112) "..., the learning outcomes from the student interaction pattern promoted by the use of cooperative, competitive and individualistic goal structures". The uses of PBL as a base in modules facilitate the students to work in groups so that students are able to develop their potential in learning. As explained Ferreira \& Trudel (2012, p. 29), "Because the problem-based learning requires that students solve problems collaboratively, the use of this approach has the potential of greatly influencing the atmosphere in the classroom." The use of thematic-integrative modules with PBL emphasizes the student cooperation to find solutions to problem-solving because a module makes the model of PBL as a major step in the preparation of the learning activity.

A function of the module in learning is to encourage the students to be an independent learner and active so that students can learn the module without needing the guidance of teachers. The use of the module with a PBL model in the learning process aimed at reducing the duties of teachers so that teachers simply acted as a facilitator who encourages students to be more self-sufficient and actively involved directly. As described by English \& Kitsantas (2013, p. 131) explained that.

"The teacher's primary role in the PBL is to structure activities to stimulate motivation and encourage reflection and to facilitate learning through scaffolding, feedback, guidance and 
prompts for thinking. The student's role in the PBL is to take responsibility for their learning and make meaning of the knowledge and concepts they encounter."

The teacher acts as a facilitator, and the students acts actively engaged in learning and responsible for their education. The steps of learning in a PBL is able to make the students more responsible for learning so that encourages the students' independent learning to actively seeking data, strategize, make conjectures, piloting, and concluded its own solution from the problems.

The using of learning module with Problem-Based Learning as a basic in thematicintegrative modules also plays a role in enhancing the independent learning of the student. Problembased learning provided an opportunity to students to further study independently, freely exchange thoughts with friends, and help each other be grouped in completing a task or students worksheets which given by the teacher (Handika \& Wangid, 2013, p. 91). The Independent learning of students in PBL learning gained through the presentation of a problem in a real and close to students' neighbourhood. PBL learning encourages students to be independent in their learning with the guidance of teachers because students are asking questions and looking for the solution of these questions which encourage the students to complete the task independently (Arends, 2012, p. 399). Thus, learning using appropriate stages of PBL encourages the students to actively improve their independent learning especially learning in grade $\mathrm{V}$ at $\mathrm{SD}$ Pudokusuman using integrative thematic learning modules with Problem-Based Learning.

PBL learning uses the real problems in real life as the main focus of learning so that learning directed at the active involvement of students to solve the problems. Waridah \& Aman (2015, p. 214) explained that the experience learned in school that is relevant to the lives of the learners will help students to solve problems in daily life and can provide learning how to interact with the community. PBL was able to direct the students to work together with other students to discuss, share the ideas and solve problems so that the students actively interact with other. A study explained that if learning involving the students actively in the learning process in performing the discovery and investigate information will be able to improve the learning outcomes of students. Research by Akcay (2009, p. 29) also explained that the students become independent learners who are capable to investigate the information, following the discovery and active learning if the students in PBL acted as a real investigator and an active learner. ProblemBased Learning is able to encourage the students to actively gain experience of learning through problem-solving activities. In addition, aiming to increase the independent learning, ProblemBased Learning model is also able to improve the learning outcome. Another study by Tarhan \& Sesen (2013, p. 575) found that PBL is a model that is able to give a positive effect on the achievement, an alternative to embedding the concept, and the development of social skills. Problem-Based Learning is able to facilitate the students in acquiring the knowledge, attitudes, and skills in the learning process.

A number of researches support the explanation of the importance of integrative thematic learning module with PBL in a learning activity. Research on the application of the supporting materials such as either the module or book is able to enhance the learning process. Indah Kurniawati, Wahyuni \& Putra conducted research using comics and local wisdom in Jember as the Integrated Science learning materials. The study found out that the utilization of complementary learning materials such as comics and the local wisdom media is able to enhance the implementation of the learning process and motivate the students (Kurniawati, Wahyuni \& Putra, 2017, p. 49). The complementary materials such as comics, books or modules may use as a means for teachers in optimizing learning. The using the complementary materials are able to facilitate the students in independent. Here, the teacher acts only as a facilitator. Another research by Shafii \& Yasin (2013, p. 221), also developed a module with PBL that the module is able to encourage the students in independent learning. Thematic-integrative learning modules use PBL as learning activity so that the students involve in learning activities and participate actively studying material in depth by putting the problem as a key of learning.

PBL models that serve as a base in the thematic-integrative module was proven to increase the students' independent learning in grade $\mathrm{V}$. The reason is that the model of PBL is able to facilitate the students to be independent in solving problems and working in the group. In line with Akcay conducted research on PBL model in science learning. Akcay (2009, p. 34) concluded that students gain knowledge when in the PBL, then they become skilled in solving the 
problems, independent learning and participate actively in learning. PBL encourages the students to be an investigator in solving real problems, become active learners, and independent learners who are able to find and manage the information, and finally, they find a solution to the problem.

Other studies by Selcuk, Emiroglu, Tarakci, \& Ozel, entitled An Integrated, Problem-Based Learning Materials: The "satellite" module. The research of integrated learning used learning materials and model of PBL modules. The study found that the use of the module and the PBL models are able to develop the students' ability to investigate a problem in real life both inside and outside of class (Selcuk, Emiroglu, Tarakci, Ozel, 2011, p. 1). PBL models able to facilitate students to develop their learning skills and critical thinking to solve the problem. In short, it is able to improve the students' learning outcomes. Research proves that the use of materials-based PBL able to improve students' learning outcomes. Then, research conducted by Musriadi, Rubiah \& Jailani on the module with PBL on the material of fungi (mushroom) concept as a guide to teachers and students in the learning process. The findings found out and prove that learning with the module-with PBL was able to improve the results of the study. In addition, Musriadi, Rubiah \& Jailani (2016, p. 39) explained that learning using module able to improve the students' learning outcomes. Learning uses the module as a complementary of learning materials in a learning process aiming at making students as active learners and reducing the teacher's role.

Thematic-integrative learning module with PBL is a learning module which facilitates the students to increase the independent learning and student learning outcomes. The advantages of thematic-integrative learning modules with PBL are the delivery of material and encourage the curiosity of the students through the problems in learning. Moreover, the thematic-integrative learning modules with Problem-Based Learning also encourages the students to be able to discuss and manage the information from the module and students' book or other learning resources which support to solve the problem. The steps of the learning activities in the thematic-integrative module also easier understand because the module is able to provide the material for independent learning during the study so that the role of the teacher is only as the facilitator. Thematic-integrative learning modules with PBL is also features of independent assessment rubric and practice which aims to measure the extent to which the student's mastery and learning results.

Based on the discussion, the thematicintegrative learning modules with ProblemBased Learning on theme 9 "Lingkungan Sahabat Kita" and sub-themes 3 "Usaha Pelestarian Lingkungan" for the grade $\mathrm{V}$ in elementary school was able to increase independent learning and learning outcomes.

\section{Conclusion}

Thematic-integrative learning module with PBL on sub-themes "Lingkungan Sahabat Kita" for grade $\mathrm{V}$ at SD Negeri Pudjokusuman 1 Yogyakarta is feasible and can be used in learning, assessed from aspects of the media, materials, the response of teachers, and response of students. Thematic-integrative learning modules with PBL on sub-themes "Lingungan Sahabat Kita" for grade V at SD Negeri Pudjokusuman 1 Yogyakarta is effective to increase the independent learning and the students' learning outcomes.

\section{References}

Akcay, B. (2009). Problem-based learning in science education. Turkish Science Education, 6, 26-36.

Anderson, L. W., \& Krathwohl, D. R. (2001). A taxonomy for learning, teaching, and assesing (A revision of bloom's taxonomy of educational objectives). New York, NY.: Addision Wesley Longman, Inc.

Arends, R. I. (2012). Learning to teach. New York: Mc Graw Hill.

Arends, R. I. \& Kilcher, A. (2010). Teaching for student learning becoming an accomplished teacher. New York, N.Y.: Routledge

Arikunto, S. (2013). Dasar-dasar evaluasi pendidikan. Jakarta: PT Bumi Aksara.

Borg, W. R. \& Gall, M. D. (1983). Educational research and development. New York \& London: Longman Inc.

Chester, V. (2009). Therelationship between cooperative learning and physics achievement in minority students. Dissertation, Walden University, 2009. UMI Dissertation Publishing.

Demirel, M., \& Dagyar, M. (2016). Effects of problem-based learning on attitude: a metaanalysis study. Eurasia Journal of 
Mathematics, Science \& Tecnology Education, 12, 2115-2137.

English, M. C. \& Kitsantas, A. (2013). Supporting stundent self-regulated learning in problem and project based learning.Interdisciplinary Journal of Problem-Based Learning, 7, 128-150.

Fogarty, R. (1991). How to integrated the curricula. Illinois: IRI/Skylight Publishing, Inc.

Ferreira, M. M., \& Trudel, A. R. (2012). The impact of problem-based learning (pbl) on student attitudes toward science, problemsolving skills sense of community in the classroom. Journal of Classroom Interaction, 47, 23-30.

Goodman, L. (1990). Time and learning in the special education classroom. New York: State University of New York Press.

Holstein, H. (1994). Murid belajar mandiri situasi belajar mandiri dalam pelajaran sekolah (Editor Dedy Suardi). Bandung: PT Remaja Rosdakarya.

Handika, I., \& Wangid, M. N. (2013). Pengaruh pembelajaran berbasis masalah terhadap penguasaan konsep dan keterampilan proses sains siswa kelas v. Jurnal Prima Edukasia, $\quad$ 1(1), 85-93. doi:http://dx.doi.org/10.21831/jpe.v1i1.23 20

Kurniawati, A A., Wahyuni, S., \& Putra, P. D. A. (2017). Utilizing of comic and jember's local wisdom as integrated science learning material. International Journal of Science and Humanity, 7, 47-50.

Koenig, R. (2010). Learning for keeps teaching the strategi essential for creating independent learning. Alexandria: ASCD.

Majid, A. (2014). Pembelajaran tematik terpadu. Bandung: Remaja Rosdakarya.

Miller, P. W. (2008). Measurement and teaching. Indiana: Library Congress Control.

Musriadi, R., \& Jailani. (2016). The development of fungi concept modul using based problem learning as a guide for teachers and students. Journal of Arts, Science \& Commerce, 7, 34-40.
Prastowo, A. (2015). Panduan kreatif membuat bahan ajar inovatif menciptakan metode pembelajaran yang menarik dan menyenangkan. Yogyakarta: Diva Press.

Selcuk, G. S., Emiroglu, H. B., Tarakci, M., \& Ozel, M. (2011). An integrated, problembased learning material: the "satelite" module. Asia-Pacific Forum on Science Learning and Teaching, 12, 1-32.

Sumantri, M. S. \& Satriani, R. (2016). The effect of formative testing and self-directed learning on mathematics learning outcomes. International Electronic Journal of Elementary Education, 8, 507524.

Syafii, W.\& Yasin, R. M. (2013). Problem solving skills and learning achievements through problem-based module in teaching and learning biology in high school. Asian Social Science, 9, 220-228.

Tarhan, L.\& Sesen, B. A. (2013). Problem-Based Learning inching acids and bases: learning achievements and students' beliefs. Journal of Baltic Science Education, 12, 565-578.

Wangid, M. N., Mustadi, A., Erviana, V., \& Arifin, S. (2014). Kesiapan guru SD dalam pelaksanaan pembelajaran tematikintegratif pada Kurikulum 2013 di DIY. Jurnal Prima Edukasia, 2(2), 175$182 . \quad$ doi :http://dx.doi.org/10.21831/jpe.v2i2.2717

Waridah, W., \& Aman, A. (2015). Pengembangan perangkat pembelajaran tematik-integratif tema menghargai jasa pahlawan berbasis sosiokultural di sekolah dasar. Jurnal Prima Edukasia, 3(2), 213 226.

doi:http://dx.doi.org/10.21831/jpe.v3i2.64 65

Yastika, N., \& Haryanto, H. (2016). Pengaruh metode PBL dan metode expository terhadap hasil belajar matematika pada siswa kelas V. Jurnal Prima Edukasia, 4(1), $\quad 107 \quad$ - 119. doi:http://dx.doi.org/10.21831/jpe.v4i1.77 16 